\author{
$\stackrel{\circ}{11}$ \\ $\stackrel{\circ}{\|}$

\section{JAKOŚĆ KOMUNIKACJI W ZWIĄZKU A KOMPENSUJĄCA ROLA AKTYWNOŚCI W SIECI}

\begin{abstract}
Kinga Siemiątkowska, Monika Obrębska, Jakość komunikacji w zwiq̨zku a kompensujq̨ca rola aktywności w sieci [The quality of communication in a relationship and a compensating role of Internet activity] edited by M. Obrębska, L. Bakiera „"Człowiek i Społeczeństwo" vol. L: Psychologiczne konteksty komunikacji interpersonalnej [Psychological contexts of interpersonal communication], Poznań 2020, pp. 127-138, Adam Mickiewicz University. ISSN 0239-3271, https://doi.org/10.14746/cis.2020.50.9.
\end{abstract}

The main purpose of this study was to check whether there are relationships between the partner's communication behaviours and online activity. The aspect of online activity was divided into: self-disclosure, support-seeking, making and keeping interpersonal contacts. To measure it, an authorial tool was used, called the Questionnaire of Activity in The Internet's Social Space. In order to measure the partner's communication behaviours, the Communication in Marriage Questionnaire (Kaźmierczak and Plopa) was used. It includes the following dimensions: support, commitment, depreciation. It was assumed that the partner's depreciation will correlate positively, and both the partner's support and commitment negatively with individual dimensions of online activity. The group of respondents consisted 85 women and 63 men, aged 19 to 71 . The results showed that there is a positive correlation between partner's depreciation and also a negative correlation between partner's support and online supportseeking. No other hypotheses regarding the relationship between partner's communication and online activity were confirmed. The correlation between the partner's commitment and online self-disclosure turned out to be positive and therefore opposite to the assumption. Age was considered a variable that could have an impact on this unexpected result, as it negatively correlates with both the partner's commitment and all dimensions of online activity.

Keywords: communication in relationships, online activity, Internet

Kinga Siemiątkowska, absolwentka, Wydział Psychologii i Kognitywistyki UAM, ul. A. Szamarzewskiego 89/AB, 60-568 Poznań, kinsie@st.amu.edu.pl.

Monika Obrębska, Uniwersytet im. Adama Mickiewicza w Poznaniu, Wydział Psychologii i Kognitywistyki, ul. A. Szamarzewskiego 89/AB, 60-568 Poznań, obrebska@amu.edu.pl, ORCID: https://orcid.org/0000-0003-0457-5402. 


\section{Wprowadzenie}

Jak wskazuje wiele badań (Doroszewicz, 2008) bliskie związki interpersonalne mają duże znaczenie dla odczuwanego szczęścia oraz satysfakcji z życia. Z kolei tym, co w istotny sposób wpływa na jakość związku, przyczyniając się do rozwoju miłości i wzmacniania więzi, jest komunikacja interpersonalna. Prawidłowa komunikacja pomiędzy partnerami powinna polegać przede wszystkim na okazywaniu sobie uczuć, szacunku i akceptacji, zainteresowaniu sukcesami i problemami partnera, a także przejawianiu troski (Kaźmierczak i Plopa, 2012). Powinna sprzyjać więc otwartości, bliskości oraz dawać partnerom poczucie, że są dla siebie ważni, mogą otwarcie dzielić się ze sobą swoimi myślami i doświadczeniami, a w razie potrzeby liczyć na wsparcie. Niewystarczające zainteresowanie ze strony partnera, brak jego wsparcia, akceptacji lub agresywne zachowania mogą sprawić, że jednostka zacznie szukać w sieci tego, czego nie otrzymuje w rzeczywistej relacji.

Internet jest codziennie obecny w życiu ogromnej ilości ludzi, dostarczając im niezliczonych możliwości. Dla niektórych ma on duże znaczenie ze względu na dostęp do rozmaitych informacji, inni korzystają z niego głównie w celach rozrywkowych, a jeszcze inni najbardziej doceniają internet jako narzędzie ułatwiające komunikację. Jednak ze społecznego punktu widzenia fenomen internetu związany jest z tym, że stał się on naturalnym środowiskiem funkcjonowania społecznego, umożliwiającym i ułatwiającym zaspokojenie ważnych potrzeb i motywacji społecznych. Z tego powodu od lat budzi zainteresowanie wielu psychologów społecznych, którzy skupiają się głównie na badaniu aktywności człowieka w sieci oraz związków pomiędzy internetem a innymi obszarami życia psychicznego i społecznego jednostki (Zając i Krejtz, 2007).

W badaniach psychologicznych (Young i de Abreu, 2011; Kardefelt-Winther, 2014) zwraca się uwagę na kompensującą funkcję internetu, gdyż może on być źródłem zaspokojenia tych potrzeb, które nie zostają wystarczająco zaspokojone poza nim. Internet pozwala na kontakt z innymi, dzielenie się swoimi myślami, doświadczeniami lub uczuciami, zarówno tymi pozytywnymi, jak i negatywnymi. Dzięki temu użytkownik może uzyskać tam wsparcie, zainteresowanie oraz akceptację ze strony innych użytkowników. Należy spodziewać się, że dla osoby, której partner okazuje zbyt wiele negatywnych lub niewystarczająco pozytywnych zachowań komunikacyjnych, pewne 
aktywności w internecie mogą pełnić funkcję kompensacyjną. Sprawdzenie tej zależności było głównym celem prezentowanej pracy.

\section{Istota i znaczenie komunikacji w bliskich związkach}

Dzięki komunikacji możliwa jest nie tylko wymiana informacji, ale też budowanie relacji interpersonalnych i pogłębianie więzi. Komunikacja małżeńska stanowi jeden z najważniejszych czynników, które warunkują jakość łączącej małżonków relacji, a przede wszystkim więzi uczuciowej, odzwierciedlając stopień ich wzajemnej sympatii i zaufania. Ukazuje klimat emocjonalny małżeństwa i stopień zaangażowania w życie małżeńskie (Harwas-Napierała, 2008). Dojrzała komunikacja interpersonalna pozwala na skuteczne kształtowanie relacji, rozwiązywanie wielu spraw związanych z życiem codziennym, takich jak np. podział domowych obowiązków i zarządzanie finansami, a także efektywne radzenie sobie z pojawiającymi się między partnerami sytuacjami konfliktowymi (Krok, 2015). Prawidłowa komunikacja pomiędzy małżonkami powinna umożliwiać i ułatwiać wzajemne zrozumienie, a także doświadczanie intymności. Jej efektywność zależy od jednoznacznych, zrozumiałych wiadomości werbalnych i niewerbalnych przekazywanych przez partnerów. Celem komunikacji w tak intymnej relacji, jaką jest związek małżeński, oprócz efektywnego porozumiewania się powinno być też przede wszystkim wspieranie bliskości (Kaźmierczak i Plopa, 2012).

Partnerzy w procesie komunikacji przekazują jednocześnie na metapoziomie informację o sobie, innych i o związku. Proces obiegu informacji jest kołowy, tak więc wiadomości dostarczane przez jednego z partnerów wpływają na reakcję drugiej osoby, powodując sprzężenie zwrotne. Mąż, reagując na komunikaty żony odnośnie do jej obrazu samej siebie, obrazu jego osoby i obrazu związku, wpływa zwrotnie na jej myśli i reakcje. Niezwykle ważną rolę w relacji małżeńskiej odgrywają wzajemne wzmocnienia, które mają miejsce, kiedy komunikaty o wzajemnym zaangażowaniu, trosce i szacunku dostarczane są w sprzężeniu zwrotnym. Funkcję wzmocnień pełni też wyrażanie pozytywnych uczuć o związku, wykazywanie zainteresowania i zaangażowania w jego jakość i budowanie trwałości. Istotne jest również wyrażanie znaczenia i wyjątkowości drugiej osoby, radości z jej istnienia oraz aprobowanie tego, jak ona wyraża doświadczanie siebie. Umocnienia mogą być przekazywane zarówno przez słowa, jak i zachowania świadczące o zaangażowaniu czy szacunku do partnera. Działają one 
wzmacniająco na relację, wpływają na poprawę poczucia własnej wartości i kształtują poczucie bezpieczeństwa w związku, co prowadzi do budowania intymności, rozwija otwartą postawę względem innych i wzbudza motywację do stawiania czoła małżeńskim wyzwaniom (Kaźmierczak i Plopa, 2012).

Nieuniknionym, naturalnym elementem życia małżeńskiego są nieporozumienia i konflikty (Plopa, 2005), których istotą jest „zderzenie przeciwstawnych potrzeb, poglądów, dążeń, życzeń, oczekiwań” (Ryś, 2004: 60). Ich źródło może leżeć również w braku komunikacji lub w problemach z umiejętnym komunikowaniem się. Brak komunikacji uniemożliwia sprostanie oczekiwaniom drugiej osoby, gdyż nie pozwala na poznanie jej uczuć ani potrzeb (Liberska i Matuszewska, 2001). Trudności w komunikowaniu się mogą obejmować m.in. niejasne, niefortunne przekazywanie treści, a co za tym idzie - interpretowanie ich przez odbiorcę niezgodnie z intencją partnera. Przyczyną nieporozumień jest też niekiedy nieuważne lub wybiórcze przyjmowanie przekazywanych wiadomości przez odbiorcę, który podświadomie stara się nie dopuścić do podważenia jego własnego poglądu w danej kwestii (Celmer, 1989).

Sposób komunikowania się może się przyczynić nie tylko do powstawania sytuacji konfliktowych, ale również mieć wpływ na ich rozwiązanie, jednocześnie wzmacniając lub niszcząc związek. Maria Ryś (2004) dokonała podziału konfliktów na integrujące i dezintegrujące, biorąc pod uwagę ich znaczenie dla relacji małżeńskich i rodzinnych. W przypadku konfliktów o charakterze integrującym komunikacja jest jasna i przejrzysta, a komunikaty werbalne odpowiadają niewerbalnym. Przedmiot sporu dotyczy konkretnych, określonych faktów, a partnerzy nie uderzają wzajemnie w swoją wartość i godność. Angażują się oni wspólnie w rozwiązanie sporu, za wypowiedziane słowa i proponowane rozwiązania przyjmują pełną odpowiedzialność, a kierunek podejmowanych przez nich działań jest jasno sprecyzowany. W tego typu konfliktach emocje komunikowane są w sposób szczery, otwarty i autentyczny. Ważną rolę odgrywa humor, mający na celu rozładowanie napięcia. Konflikty takie skutkują wzajemnym przebaczeniem, wzrostem poczucia bliskości, jedności, zaufania i zrozumienia. Dzięki nim partnerzy zostają także wzbogaceni o nowe informacje i zwiększoną samokontrolę, pozwalające na lepsze radzenie sobie z przyszłymi trudnościami. Konflikty dezintegrujące, w przeciwieństwie do poprzednich, nie dotyczą konkretnych faktów, a jedynie przypuszczeń i fantazji. Partnerzy ranią się nawzajem, a zaangażowanie w rozwiązanie sytuacji konfliktowej zwykle jest jednostronne. Zazwyczaj też żaden z uczestników sporu nie chce przyjąć odpowiedzialności za jego skutki. Choć w przypadku tego typu 
konfliktów humor również może być obecny, to raczej nie pełni on funkcji rozładowywania sytuacji, lecz ma charakter ironiczny i jedynie wzmaga istniejące napięcie. Komunikaty werbalne i niewerbalne często są ze sobą sprzeczne, kierunek konfliktu nie jest określony, a konkretność jego wyniku jest trudna do uchwycenia. Wskutek takich konfliktów partnerzy oddalają się od siebie z poczuciem wyrządzonej im krzywdy, żalu, lęku i niezrozumienia, a nawet chęcią zemsty.

Biorąc pod uwagę rolę, którą prawidłowa komunikacja odgrywa w kształtowaniu jakości relacji, budowaniu intymności i zaufania czy też zapobieganiu konfliktom i ich rozwiązywaniu, nie powinno dziwić, że komunikacja między partnerami ma też istotne znaczenie dla odczuwanej satysfakcji ze związku. Według Kurta Hahlwega (2004, za: Krok i Murlowska, 2011), obecność bliskiej i otwartej komunikacji, efektywne radzenie sobie z konfliktami i emocjonalne wsparcie partnera należą do czynników, które znacząco wpływają na poziom odczuwanego zadowolenia z małżeństwa. Z kolei z badań przeprowadzonych przez Mieczysława Plopę (2005) wynika, że zarówno w przypadku kobiet, jak i mężczyzn postrzegane wsparcie oraz zaangażowana komunikacja współmałżonka oddziałują pozytywnie na satysfakcję ze związku, a z kolei deprecjonowanie ze strony partnera wpływa na nią niekorzystnie.

\section{Zachowania komunikacyjne partnera a aktywność w sieci}

Współcześnie to właśnie w internecie, a zwłaszcza na portalach społecznościowych dzięki interakcji z innymi ludźmi jesteśmy w stanie uzyskać wsparcie i zainteresowanie, których nie otrzymujemy od partnera. Mamy możliwość dzielenia się swoimi myślami i uczuciami zarówno z osobami znanymi poza środowiskiem internetowym, jak i tymi, z którymi nie mieliśmy wcześniej żadnego kontaktu. Dzięki istnieniu grup łączących użytkowników o podobnych trudnościach znalezienie pomocy, zrozumienia i akceptacji w sieci jest osiągalne (Boyd i Ellison, 2008; Varnali i Toker, 2015; Bąk, 2016).

Możliwość komunikowania się z innymi za pośrednictwem internetu może okazać się szczególnie cenna zarówno dla osób, które nie otrzymują od partnera wystarczającego zainteresowania ich uczuciami i problemami, jak i tych, które spotykają się z jego strony z obwinianiem, krytyką i brakiem zrozumienia. Zdaniem Kimberly S. Young (1998), używanie internetu przyczynia się do łagodzenia nastrojów dysforycznych i bywa sposobem 
na radzenie sobie lub kompensowanie problemów z realnego życia. Internet może więc odgrywać dużą rolę w przezwyciężaniu poczucia samotności, depresji czy też niskiej samooceny. Young i Cristiano Nabuco de Abreu (2011) zwrócili uwagę na to, że jednym z czynników uzależnienia od Facebooka może być chęć zaspokojenia tych potrzeb społecznych, które nie zostają wystarczająco zaspokojone poza internetem. Podobnie Scott Caplan i Andrew C. High (2011, za: Kardefelt-Winther, 2014) stwierdzili, że poprzez wymianę wiadomości internetowych z innymi użytkownikami ludzie kompensują to, czego brakuje im w prawdziwym życiu.

Na tych założeniach bazuje teoria kompensacyjnego używania internetu (Kardefelt-Winther, 2014), zgodnie z którą negatywne sytuacje życiowe mogą być motywacją do korzystania z sieci w celu załagodzenia negatywnych odczuć. Osoba, której brakuje kontaktów społecznych, będzie szukać ich w serwisach internetowych czy też grach sieciowych umożliwiających interakcję z innymi użytkownikami. Można więc przypuszczać, że brak satysfakcji z komunikacji w związku również nie pozostaje bez wpływu na aktywność podejmowaną w środowisku internetowym. Kiedy partnerzy nie dają sobie tego, czego potrzebują, źródłem kompensacji może stać się właśnie internet.

\section{Metodologia badania własnego}

Zgodnie z założeniami teorii kompensacyjnego używania internetu (Kardefelt-Winther, 2014) przypuszczać można, że aktywność podejmowana w sieci ma związek z jakością komunikacji w związku oraz że dla osoby, której partner okazuje zbyt wiele negatywnych lub niewystarczająco pozytywnych zachowań komunikacyjnych, pewne aktywności w internecie mogą pełnić funkcję kompensacyjną. W badaniu własnym założyłyśmy istnienie dodatniego związku pomiędzy spostrzeganą deprecjacją ze strony partnera a podejmowaniem różnych form aktywności w sieci, takich jak: poszukiwanie wsparcia, samoujawnianie, nawiązywanie i utrzymywanie kontaktów interpersonalnych oraz istnienie związku ujemnego pomiędzy spostrzeganymi pozytywnymi zachowaniami komunikacyjnymi partnera (jak wsparcie i zaangażowanie) a aktywnością w sieci. W badaniu uwzględnione zostały również takie zmienne demograficzne jak: płeć, wiek i staż związku.

W celu pomiaru zmiennej niezależnej, jaką są zachowania komunikacyjne partnera, zastosowano Kwestionariusz Komunikacji Małżeńskiej i Partnerskiej, opracowany przez Marię Kaźmierczak i Mieczysława Plopę. 
Składa się on z 30 pozycji i obejmuje trzy wymiary, określające poszczególne zachowania komunikacyjne:

- wsparcie (10 pozycji) - oznacza przejawianie szacunku partnerowi poprzez docenianie jego wysiłków, okazywanie zainteresowania problemami i potrzebami partnera, a także aktywne uczestnictwo we wspólnym rozwiązywaniu tych problemów;

- zaangażowanie (9 pozycji) - oznacza umiejętność tworzenia atmosfery wzajemnej bliskości i zrozumienia poprzez okazywanie sobie uczuć, akcentowanie wyjątkowości i ważności partnera, zapobieganie konfliktom w związku, urozmaicanie rutyny dnia codziennego;

- deprecjacja (11 pozycji) - oznacza przejawianie zachowań agresywnych wobec partnera, chęć zdominowania go i kontrolowania jego działań, a także brak poszanowania godności partnera.

Do pomiaru zmiennej „aktywność w sieci” zastosowano autorski Kwestionariusz Aktywności w Społecznej Przestrzeni Internetu, składający się z 18 stwierdzeń, odpowiadających następującym wymiarom:

- samoujawnianie (8 pozycji) - odnosi się do zachowań związanych z ujawnianiem w sieci swoich myśli, uczuć, doświadczeń i innych informacji o sobie;

- poszukiwanie wsparcia (5 pozycji) - obejmuje stwierdzenia dotyczące zachowań związanych z szukaniem wsparcia w sieci w przypadku zmartwień i problemów, ale też z poszukiwaniem poparcia lub motywacji;

- nawiązywanie i utrzymywanie kontaktów interpersonalnych (5 pozycji) - dotyczy tych aktywności w sieci, które nastawione są na zaspokojenie potrzeby kontaktu, komunikacji z innymi.

Współczynniki rzetelności alfa Cronbacha dla poszczególnych wymiarów kwestionariusza wynoszą kolejno: 0,87 dla samoujawniania, 0,79 dla poszukiwania wsparcia oraz 0,69 dla nawiązywania i utrzymywania kontaktów interpersonalnych.

Badanie zostało przeprowadzone z wykorzystaniem internetu. O wypełnienie ankiety poproszono osoby, które aktualnie były w związku partnerskim. W badaniu wzięło udział 148 osób, w tym 85 kobiet oraz 63 mężczyzn. Wiek badanych zawierał się w przedziale od 19 do 71 lat, a jego średnia wyniosła 39 lat. Wśród badanych 100 osób posiadało wykształcenie wyższe (67,6\%), 40 osób wykształcenie średnie (27\%), 7 osób wykształcenie zasadnicze zawodowe $(4,7 \%)$ oraz 1 osoba wykształcenie gimnazjalne $(0,7 \%)$. Najkrótszy staż związku wyniósł mniej niż rok, a najdłuższy - 50 lat. Średnia długość trwania związku to 15 lat. 


\section{Wyniki}

W badaniu założono, że zachowania deprecjonujące ze strony partnera sprzyjają podejmowaniu przez jednostkę aktywności związanych z poszukiwaniem wsparcia, samoujawnianiem oraz nawiązywaniem i utrzymywaniem kontaktów interpersonalnych w sieci. Wyniki analiz potwierdziły jedynie pierwszą hipotezę, wskazując na słaby dodatni związek pomiędzy oceną poziomu deprecjacji ze strony partnera a poszukiwaniem wsparcia w sieci $\left(r_{s}=0,17 ; p<0,05\right)$. Można stwierdzić, że im bardziej deprecjonujący jest partner, tym większą skłonność jednostka wykazuje do poszukiwania wsparcia w internecie. Hipotezy dotyczące związku zachowań deprecjonujących ze strony partnera z pozostałymi wymiarami aktywności w sieci nie zostały potwierdzone. Wyniki analiz nie potwierdziły przypuszczeń, że wraz ze wzrostem oceny deprecjacji ze strony partnera wzrasta skłonność do podejmowania w sieci zachowań związanych z samujawnianiem $\left(r_{s}=0,06 ; p>0,05\right)$ oraz nawiązywaniem i utrzymywaniem kontaktów interpersonalnych $\left(r_{s}=0,03 ; p>0,05\right)$.

Kolejne założenie dotyczyło ujemnego związku pozytywnych zachowań komunikacyjnych partnera, takich jak wsparcie oraz zaangażowanie, z poszczególnymi wymiarami aktywności w sieci. Założono, że niższe oceny wsparcia i zaangażowania ze strony partnera będą sprzyjały podejmowaniu w sieci aktywności związanych z poszukiwaniem wsparcia, samoujawnianiem oraz nawiązywaniem i utrzymywaniem kontaktów interpersonalnych. Wyniki wskazały na słaby ujemny związek pomiędzy oceną poziomu wsparcia ze strony partnera a poszukiwaniem wsparcia w sieci $\left(r_{s}=-0,14\right.$; $p<0,05)$. Na ich podstawie można stwierdzić, że im mniej wspierający jest partner, tym jednostka chętniej poszukuje wsparcia w internecie. Pozostałe hipotezy, dotyczące ujemnego związku wsparcia ze strony partnera z samoujawnianiem $\left(r_{s}=0,05 ; p>0,05\right)$ oraz nawiązywaniem i utrzymywaniem kontaktów interpersonalnych $\left(r_{s}=-0,006 ; p>0,05\right)$, a także ujemnego związku zaangażowania ze strony partnera z trzema poszczególnymi wymiarami aktywności w sieci, nie zostały potwierdzone. Zaobserwowano jedynie słaby dodatni związek pomiędzy oceną zaangażowania partnera a samoujawnianiem w sieci $\left(r_{s}=0,16 ; p<0,05\right)$.

Sprawdzono również, czy istnieją różnice pomiędzy kobietami i mężczyznami w ocenie zachowań komunikacyjnych partnera i w zakresie aktywności w sieci. Wynik okazał się istotny statystycznie jedynie w przypadku 
deprecjacji $(U=1816 ; p<0,05)$ i samoujawniania $(U=2068$; $p<0,05)$. Mężczyźni $(M=88,17)$ istotnie częściej niż kobiety $(M=64,36)$ oceniali zachowanie komunikacyjne partnera jako deprecjonujące oraz stosowali samoujawnianie w sieci $(M=84,17 ; M=67,34)$. Stwierdzono również istotne związki pomiędzy wiekiem a aktywnością w sieci. Dla samoujawniania oraz poszukiwania wsparcia współczynnik korelacji wynosił -0,34, a dla nawiązywania i utrzymywania kontaktów interpersonalnych $-0,35$. Świadczy to o umiarkowanym ujemnym związku pomiędzy wiekiem a każdą z aktywności. Wiek okazał się również istotny w przypadku spostrzeganego zaangażowania partnera: im wyższy wiek, tym niższa ocena zaangażowania partnera $\left(r_{s}=-0,24 ; p<0,05\right)$. Podobną zależność stwierdzono również w przypadku długości stażu związku: im dłuższy staż, tym niższa ocena zaangażowania $\left(r_{s}=-0,2 ; p<0,05\right)$.

\section{Dyskusja wyników}

Celem przeprowadzonych badań było zweryfikowanie związków pomiędzy zachowaniami komunikacyjnymi partnera a aktywnością w sieci. Wychodząc z założenia, że aktywność w internecie może rekompensować słabej jakości komunikację z partnerem, starano się ustalić, czy istnieje związek pomiędzy spostrzeganym wsparciem, zaangażowaniem i deprecjacją partnera a trzema wymiarami aktywności w sieci: samoujawnianiem, poszukiwaniem wsparcia oraz nawiązywaniem i utrzymywaniem kontaktów interpersonalnych. Dodatkowo sprawdzano również różnice pomiędzy kobietami i mężczyznami w zakresie oceny zachowań komunikacyjnych partnera oraz aktywności podejmowanej w sieci. Ponadto weryfikowano zależności pomiędzy wiekiem i stażem związku a oceną zachowań komunikacyjnych partnera, a także pomiędzy wiekiem a podejmowaniem poszczególnych rodzajów aktywności w sieci.

Choć uzyskane wyniki nie potwierdziły wszystkich postawionych w pracy hipotez, to jednak dostarczyły kilku interesujących informacji, skłaniających do dalszych badań w obszarze komunikacji interpersonalnej. Zgodnie z założeniami teorii kompensacyjnego używania internetu (Kardefelt-Winther, 2014) wykazano, że osoby, które oceniają swoich partnerów zarówno jako mniej wspierających, jak i bardziej deprecjonujących, cechują się większą skłonnością do poszukiwania wsparcia w sieci. Wykazano również, że im większe postrzegane zaangażowanie partnera, tym większa skłonność do samoujawniania. Uzasadnieniem tego niezgodnego z oczekiwaniami wyniku może być uzyskana zależność pomiędzy wiekiem a oceną komunikacji 
partnera, a także wiekiem i aktywnością w sieci. Okazało się, że wraz z wiekiem maleje zarówno ocena zaangażowania partnera, jak i skłonność do podejmowania wszystkich trzech aktywności w sieci, w tym samoujawniania. Wobec tego można przypuszczać, że dodatni związek zaangażowania z samoujawnianiem jest korelacją pozorną, wynikającą z wieku osób badanych, który pełnić może funkcję mediującą zakładane zależności.

Wyniki analiz dotyczących różnic pomiędzy kobietami i mężczyznami w ocenie zachowań komunikacyjnych partnera potwierdzają spostrzeżenia Zofii Pupin i Jacka Waldmajera (2013), którzy również wykazali, że w wymiarze „deprecjacja” mężczyźni surowiej oceniają swoje partnerki niż kobiety partnerów. Kobiety w związkach częściej spostrzegane są przez mężczyzn jako dominujące i kontrolujące, wyrażające negatywne oceny i agresywne sądy. Taka ocena kobiet przez mężczyzn wynikać może z szerszego kontekstu społeczno-kulturowego, nazywanego w literaturze „kryzysem męskości” (Melosik, 2002) lub „porażką patriarchalnych męskich wartości” (Zimbardo i Coulombe, 2015). Wymaga to z pewnością szerszych analiz i pogłębionych studiów, uwzględniających zmiany w oczekiwaniach społecznych i rolach płciowych związanych z funkcjonowaniem kobiet i mężczyzn w związkach partnerskich.

Zaskakujący okazał się również wynik dotyczący różnic płciowych w podejmowaniu aktywności w sieci, pokazujący, że mężczyźni chętniej niż kobiety podejmują aktywność związaną z samoujawnianiem w internecie. W świetle dotychczasowych badań, dotyczących zarówno samoujawniania w świecie wirtualnym, jak i poza nim, to kobiety zwykle chętniej inicjują proces samoujawniania oraz w nim uczestniczą (Sanecka, 2014). Choć wyniki badań przedstawione w niniejszej pracy wskazują na różnicę istotną statystycznie jedynie w przypadku samoujawniania, to również w pozostałych wymiarach aktywności w sieci średnia mężczyzn jest nieco wyższa niż kobiet. Wynik ten dotyczy szczególnie młodych mężczyzn, gdyż jak wykazało badanie - korzystanie z internetu jest domeną osób młodych.

W przypadku ujemnej korelacji wieku z zaangażowaniem partnera można domyślać się, że jest ona związana z zazwyczaj dłuższym stażem związku osób starszych - wraz z rosnącą długością trwania związku, tak samo jak i wzrostem wieku, spada ocena zaangażowania partnera. Wyniki uzyskane przez Pupin i Waldmajera (2013), którzy zbadali różnice w komunikacji osób z krótkim i długim stażem małżeńskim, również wskazały na związek zaangażowania z długością trwania związku. Jak się okazało, zaangażowanie w związku małżeńskim jest większe w przypadku osób o stażu krótszym, trwającym do czterech lat, niż dłuższym, trwającym powyżej czterech lat. 
Rezultat ten odnosi się zarówno do oceny zachowań własnych, jak i zachowań partnera. Zgodnie ze stwierdzeniem autorów, może to wskazywać na większe zorientowanie na samopoczucie partnera oraz większą atrakcyjność związku na początku jego trwania.

Uzyskane wyniki nie pozwalają jednoznaczne rozstrzygnąć, czy aktywność w sieci kompensuje to, czego brakuje w komunikacji z partnerem. Można przypuszczać, że funkcję taką pełni poszukiwanie wsparcia, choć uzyskane w niniejszej pracy rezultaty, dotyczące związku zachowań komunikacyjnych partnera z aktywnością w sieci, powinny stanowić jedynie punkt wyjścia do kolejnych, dokładniejszych badań. Należałoby rozważyć zawężenie badań do młodszej grupy osób lub dokonać porównania różnych grup wiekowych. Ponadto, warto byłoby wziąć pod uwagę również inne działania w sieci niż tylko te uwzględnione w niniejszej pracy. Cenna mogłaby się okazać także analiza związku zachowań komunikacyjnych partnera z konkretnymi zachowaniami w internecie, a nie tylko określonymi wymiarami. W przypadku badania związku między komunikacją z partnerem a szukaniem wsparcia w sieci warto byłoby wziąć pod uwagę, jakiego rodzaju wsparcia poszukuje się w internecie. Podjęta w niniejszej pracy tematyka dotyczy bardzo istotnych kwestii w czasach, gdy sieć stała się ważnym środowiskiem funkcjonowania społecznego, dlatego warto uwzględniać w badaniach nad komunikacją również ten rodzaj międzyludzkiej aktywności.

\section{Literatura}

Bąk, A. (2016). Serwisy społecznościowe - efekt Facebooka i nie tylko. Media i Społeczeństwo, 6, 134-146.

Boyd, D., Ellison, N. (2008). Social network sites: Definition, history, and scholarship. Journal of Computer-Mediated Communication, 13, 210-230.

Celmer, Z. (1989). Małżeństwo. Warszawa: Państwowy Zakład Wydawnictw Lekarskich.

Doroszewicz, K. (2008). Bliskie związki a jakość życia. Psychologia Jakości Życia, $7(1,2), 5-18$.

Harwas-Napierała, B. (2008). Komunikacja interpersonalna w rodzinie. Poznań: Wydawnictwo Naukowe UAM.

Kardefelt-Winther, D. (2014). A conceptual and methodological critique of internet addiction research: Towards a model of compensatory internet use. Computers in Human Behavior, 31, 351-354.

Kaźmierczak, M., Plopa, M. (2012). Komunikacja w bliskich zwiq̨zkach. Teoria i metoda badania. Warszawa: Vizja Press \& IT.

Krok, D. (2015). Satysfakcja ze związku małżeńskiego a poziom hedonistycznego i eudajmonistycznego dobrostanu psychicznego małżonków. Family Forum, 5, 141-160. 
Krok, D., Murlowska, M. (2011). Komunikacja interpersonalna między małżonkami a poziom satysfakcji z małżeństwa. W: D. Krok, D. Klejnowski-Różycki (red.), Relacje rodzinne i społeczne w kulturze środkowoeuropejskiej i chińskiej (s. 126-149). Opole: Redakcja Wydawnictw WT Uniwersytetu Opolskiego.

Liberska, H., Matuszewska, M. (2001). Wybrane psychologiczno-społeczne mechanizmy funkcjonowania małżeństwa. W: H. Liberska, M. Matuszewska (red.), Małżeństwo: męskość, kobiecość, miłość, konflikt (s. 13-28). Poznań: Wydawnictwo Fundacji Humaniora.

Melosik, Z. (2002). Kryzys męskości w kulturze współczesnej. Kraków: Oficyna Wydawnicza Impuls.

Plopa, M. (2005). Więzi w małżeństwie i rodzinie. Metody badań. Kraków: Oficyna Wydawnicza Impuls.

Pupin, Z., Waldmajer, J. (2013). Komunikacyjne zachowania w małżeństwie z perspektywy własnej i partnera. Family Forum, 3, 187-200.

Ryś, M. (2004). Jakość związku małżeńskiego a poziom bliskości małżonków i sposoby rozwiązywania przez nich konfliktów. Studia Psychologica, 5, 57-67.

Sanecka, E. (2014). Samoujawnianie online. Przegląd teorii i wyników wcześniejszych badań. W: K. Tucholska, M. Wysocka-Pleczyk (red.), Człowiek zalogowany 3 (s. 34-45). Kraków: Biblioteka Jagiellońska.

Varnali, K., Toker, A. (2015). Self-disclosure on social networking sites. Social Behavior and Personality, 43(1), 1-14.

Young, K.S. (1998). Internet addiction: The emergence of a new clinical disorder. CyberPsychology \& Behavior, 1, 237-244.

Young, K.S., de Abreu, C.N. (2011). Closing thoughts and future implications. W: K.S. Young, C.N. de Abreu (red.), Internet Addiction: A Handbook and Guide to Evaluation and Treatment (s. 267-273). Hoboken, NJ: John Wiley \& Sons.

Zając, J.M., Krejtz, K. (2007). Internet jako przedmiot i obszar badań psychologii społecznej. Psychologia Społeczna, 2, 3-4 (5), 191-200.

Zimbardo, P.G., Coulombe, N.S. (2015). Gdzie ci mężczyźni? Warszawa: Wydawnictwo Naukowe PWN. 